"Mircea cel Batran" Naval Academy Scientific Bulletin, Volume XIX - 2016 - Issue 1

Published by "Mircea cel Batran" Naval Academy Press, Constanta, Romania // The journal is indexed in:

PROQUEST / DOAJ / DRJI / JOURNAL INDEX / I2OR / SCIENCE LIBRARY INDEX / Google Scholar / Crossref /

Academic Keys / ROAD Open Access / OAJI / Academic Resources / Scientific Indexing Services / SCIPIO

\title{
THE QUALITY FACTOR OF THE NAVAL M.H.D PROPULSION SYSTEM
}

\author{
Vasile DOBREF ${ }^{1}$ \\ Paul BURLACU ${ }^{2}$ \\ Petrică POPOV ${ }^{3}$ \\ Florenţiu DELIU 4 \\ Mitruț C. CARAIVAN ${ }^{5}$ \\ ${ }^{1}$ Professor PhD eng. Naval Academy "Mircea cel Batran", Constanța, vasile.dobref@anmb.ro \\ 2Lecturer PhD eng. Naval Academy "Mircea cel Batran", Constanța, paul.burlacu@anmb.ro \\ 32Lecturer PhD Naval Academy "Mircea cel Batran", Constanța, petrica.popov@anmb.ro \\ ${ }^{4}$ Lecturer PhD eng. Naval Academy "Mircea cel Batran", Constanța, florentiu.deliu@anmb.ro \\ ${ }^{5}$ PhD eng., Naval Academy “Mircea cel Batran”, Constanța, caraivanmitrut@gmail.com
}

Abstract: A naval propulsion magnetohydrodynamic (M.H.D.) induction is actually a linear induction machine that uses seawater as induced. In seawater occurs an interaction between a magnetic field induced by the progressive currents, resulting an electromagnetic force. This force causes the movement of water, which is discharged from the vessel through a nozzle, thus creating a reactive propellant. Such a propulsion system eliminates the propeller and its annexes reducing energy losses associated with the rotation of water, noise and cavitation.

Keywords: magnetohydrodinamic; propulsion system; magnetic force

\section{Introduction}

A soundless navigation is essential for a submarine patrol in the maritime area. MHD ship propeller being a linear induction machine, characterized by the size of its effectiveness is called "the quality factor" $Q$, defined of Laithwaite as the ratio magnetizing reactance and the resistance of the armature:

$$
Q=\frac{\omega L_{2}}{R_{2}}(1)
$$

This definition follows the relationship

$$
Q=\frac{2 \tau_{p} \mu_{0} f}{\pi \frac{\rho}{\Delta} h}(2)
$$

Where:

$\tau_{p}$ is the polar step;

$\mu_{0}$-the vacuum permeability;

$\mathrm{f}$ - sequence power, resistivity; air gap $h$.

$\rho, \Delta-$ armature thickness and size of the If an induction machine with the induced seawater, applying relation (1) becomes quite difficult for obvious reasons; therefore, assume a redefinition of energy quality factor considerations. The machine absorbs from the energy source which dissipates in the form of active power and some stores as reactive energy accumulated in the air gap magnetic field.
If we denote $W_{j}$, Joule energy dissipation and $W_{m}$ magnetic field energy in air gap, this report is written as

$$
R=\frac{W_{j}}{W_{m}}(3)
$$

We believe that the electrical machine will be all the more efficiency as muh the ratio of the dissipation and accumulated energy will be higher and we propose to characterize the size MHD thruster naval by so called "energy report" $\mathrm{R}$.

We further demonstrate that the ratio of energy quality factor $\mathrm{Q}$ and $\mathrm{R}$ expresses the same physical reality. For this, we calculate the energies $W_{j}$, respectively $W_{m}$. Polyphase windings of the inductor will generate a magnetic field in the airgap, having the character of wave intensity expressed by the

$$
H(x, t)=H_{m} \sin \left(\omega t-\frac{\pi x}{\tau_{p}}\right)(4)
$$

This field is moving at synchronous speed:

$$
v_{s}=2 \tau_{p} f(5)
$$

to a designated location. If the armature is moving at speed $v$, the relative velocity to the induced magnetic field will be:

$$
v_{r}=v_{s}-v_{0}(6)
$$

The field gradually travels a distance equal to one polar step during: 
"Mircea cel Batran" Naval Academy Scientific Bulletin, Volume XIX - 2016 - Issue 1

Published by "Mircea cel Batran" Naval Academy Press, Constanta, Romania // The journal is indexed in: PROQUEST / DOAJ / DRJI / JOURNAL INDEX / I2OR / SCIENCE LIBRARY INDEX / Google Scholar / Crossref /

Academic Keys / ROAD Open Access / OAJI / Academic Resources / Scientific Indexing Services / SCIPIO

$$
t_{\tau}=\frac{\tau_{p}}{v_{s}-v}(7)
$$

Meanwhile, the induced Joule will dissipate energy expressed by the following relationship:

$$
W_{j}=\int_{0}^{t_{\tau}} P_{j}(x, t) d t(8)
$$

Joule power dissipated in an infinitesimal element of length $\mathrm{dx}$ will be induced:

$$
d P_{j}=u^{2}(x, t) d g(x)(9)
$$

where $u(x, t)$ is the induced voltage of the fieldinduced progressively element located at the $x$ coordinate of a reference point to the end of a pole located at the time $t$, and $g(x)$ is the conductivity of the armature:

$$
g=\frac{1}{R_{2}}(10)
$$

A strip of infinite length induced by low $d x$, of width equal to the width "a" of the armature conductance will be given by the following relationship:

$$
d g=\frac{1}{\rho \frac{a}{\Delta d x}}=\frac{d x}{\frac{\rho}{\Delta} a}(11)
$$

The ratio $\rho / \Delta=\rho_{s}$ is call surface resistance $[1,2]$. Induced voltage will be given by Faraday's law of induction:

$$
u(x, t)=-\frac{\partial \Phi(x, t)}{\partial t}-\operatorname{Bav}_{r}
$$

In a first step is not taken due to the first pulse period, and in this case, the energy dissipated by Joule effect induced in a portion $\tau_{p}$ of the length will be expressed by the equation:

$$
W_{j}=\int_{0}^{t_{\tau}} \int_{o}^{\tau_{p}} \frac{\mu_{o}^{2} H^{2}(x, t) a v_{r}^{2}}{2 \rho_{s}} d x d t
$$

Substituting in (13) field strength expression and performing integrations, we obtain the relationship:

$$
W_{j}=\frac{\mu_{o}^{2} H_{m}^{2} a \tau_{p}^{2} v_{r}}{2 \rho_{s}}
$$

Magnetic energy is obtained by integrating the volume of the air gap magnetic field energy density:

$$
W_{m}=\iiint_{V_{\text {int refier }}} \frac{\mu_{0} H^{2}(x, t)}{2} d x d y d z(15)
$$

Or:

$$
W_{m}=\frac{\mu_{0} H_{m}^{2}}{2} \int_{0}^{a} d y \int_{0}^{h} d z \int_{0}^{\tau_{p}} \sin ^{2}\left(\omega t-\frac{\pi x}{\tau_{p}}\right) d x
$$

After integration we get:

$$
W_{m}=\frac{\mu_{0} H_{m}^{2} a \tau_{p} h}{4}
$$

The value of ratio $\mathrm{R}$ became:

$$
R=\frac{2 \mu_{0} \tau_{p} v_{r}}{\rho_{s} h}
$$

If we introduce the sliding,

$$
s=\frac{v_{s}-v}{v_{s}}=\frac{v_{r}}{v_{s}}
$$

and given expression synchronous speed (5) one gets

$$
R=2 \pi \mathrm{s} \frac{2 \mu_{0} f \tau_{p}^{2}}{\pi \rho_{s} h}=2 \pi \mathrm{s} \frac{2 \mu_{0} f \tau_{p}^{2}}{\pi \frac{\rho}{\Delta} h}(20)
$$

During starting $s=1$ and at the moment:

$$
\frac{R}{Q}=2 \pi
$$

(Actually, the relationship 2 was deducted all at boot time).

The fact that $R / Q$ is a dimensionless constant, makes us say that both $\mathrm{R}$ and $\mathrm{Q}$ express the same physical reality: linear induction machine efficiency. That $R \neq 0$ may be due to the fact that it took into account the induced voltage pulse. So size $R$ can be used instead of $Q$ having the advantage of a clear physical sense and a simple method of calculation.

If the MHD ship propeller induction phenomena is complicated by the fact that the velocity is not uniform across the flow passage, it having a maximum value and zero axis in contact with the channel walls. To apply equation (3) if a propeller sea water, must be calculated using equations Maxwell - Hertz $W_{j}$ and $W_{m}$ energies and also taking into account hydrodynamic processes expressed by equation Navier - Stokes. The resulting differential equations systems are very complex and can only be solved using simplifying assumptions. Such a calculation is presented in [3], but the results could not be verified experimentally. We are proposing an alternative method simpler calculation that leads to similar conclusions. The slipping s can not be defined only locally: it will be a function of the form:

$$
s(x, z)=\frac{v_{s}-v(x, z)}{v_{s}}=1-\frac{v(x, z)}{v_{s}}(22)
$$


"Mircea cel Batran" Naval Academy Scientific Bulletin, Volume XIX - 2016 - Issue 1

Published by "Mircea cel Batran" Naval Academy Press, Constanta, Romania /I The journal is indexed in:

PROQUEST / DOAJ / DRJI / JOURNAL INDEX / I2OR / SCIENCE LIBRARY INDEX / Google Scholar / Crossref /

Academic Keys / ROAD Open Access / OAJI / Academic Resources / Scientific Indexing Services / SCIPIO

In the vicinity of the free surface MHD channel axis speed has maximum value : here the slipping s is:

$$
s_{0}=\frac{v_{s}-v_{0 \max }}{v_{s}}=1-\frac{v_{0 \max }}{v_{s}}(23)
$$

The ratio $\mathrm{R}$ of energy can be expressed using the average value of slip:

$$
\bar{s}=\frac{1}{2 a h} \int_{-a 0}^{+a h} \int_{0} s(x, z) d x d z
$$

Velocity value of the channel, depending on maximum speed is calculated in [4].

$$
v(x, z)=v_{0 \max } \frac{1-\frac{c h H x}{c h H a}}{1-\frac{1}{c h H a}} \frac{z^{2}}{h^{2}}
$$

$\mathrm{Ha}$ is Hartman number:

$$
H a=B_{0} a \sqrt{\frac{\tau}{\eta}}(26)
$$

$B_{0}$ is the effectiv value of the magnetic field:

$$
\begin{array}{r}
B_{0}=\frac{B_{m}}{\sqrt{2}}=\frac{\mu_{0} H_{m}}{\sqrt{2}} \text { (27) } \\
\tau=\frac{1}{\rho} \quad \text { conductivity environment (for }
\end{array}
$$

seawater $\tau 5 \Omega{ }^{1} m^{1}$ ) and $\eta$ is the dynamic viscosity. The factor $z^{2} / h^{2}$ in (25) occurred because in [4] was adopted simplifying assumption that the distribution of velocities in depth is very little influenced by the magnetic field.

$$
\bar{s}=\frac{1}{3}\left[2+s_{0}\left(1-\frac{t h H a}{H a}\right)\right](2
$$

Substituting in (24) the sliding expressed with the relation (25) is obtained:

$$
R=\frac{2 \pi}{3} \frac{2 \mu_{0} f \tau_{p}^{2}}{\pi \frac{\rho}{\Delta} h}\left[2+\mathrm{s}_{0}\left(1-\frac{t h H a}{H a}\right)\right]
$$

This relationship certainly is not perfectly correct as far as was deduced using some simplifying assumptions, but gives some information about the phenomena produced by the unevenness of flow velocity in the channel.

A first information that follows is that the flow rate of the channel axis is equal to synchronous speed the $s_{0}$ became zero; $\mathrm{R}$ does not reduce as an solid induced machine case. In this case, although the channel axis disappear inductive processes, they still present elsewhere. The forces that are generated will be zero, causing water training. Energy $\mathrm{R}$ ratio value is determined mainly by the front bracket factor in equation (29) that increases the polar and linear quadratic step frequency. MHD thruster handicap essential to naval induction resistivity comes from the large amount of sea water. E.g:

$$
\frac{\rho_{\text {seawater }}}{\rho_{\text {copper }}} \cong 10^{7}
$$

In order that the energy from the engine MHD R have the same order of magnitude as a copperinduced motor, it is necessary to be satisfied with the following relation:

$$
\frac{\left(\tau_{p}^{2} f\right) \text { seawater }}{\left(\tau_{p}^{2} f\right) \text { copper }} \cong 10^{7}
$$

Equation (31) explains that experiments with classical principles inductors designed after the armature has been replaced with a metal pipe with sea water, no conclusive results.

\section{CONCLUSION}

1. The quality factor of a linear induction machine can be expressed using the energy ratio $\mathrm{R}$, defined as the ratio of the active energy and the energy dissipated in the magnetic field induced inside.

2. An MHD ship propeller can be effective efficiency only if the product $\tau_{p}^{2} f$ is often higher than $10^{7}$ then a classic linear motor. On a classic motor $\tau_{p} \approx 10^{2} \mathrm{~m}$ and $\mathrm{f}=50 \mathrm{~Hz}$. A naval propulsion MHD induction must be designed so that $\tau_{p} \approx 1 \mathrm{~m}$ and $\mathrm{f}=50 \mathrm{kHz}$. Such sizing brings some technical difficulties can be resolved.

\section{BIBLIOGRAPHY}

[1] Laithwaite, E.R.; „Induction machines for general purposes “

[2]Botez, D.; Cantemir, L.; Cristea, I.; „Propulsia navală neconvenţională “, Editura Muntenia 1999. 
"Mircea cel Batran" Naval Academy Scientific Bulletin, Volume XIX - 2016 - Issue 1

Published by "Mircea cel Batran" Naval Academy Press, Constanta, Romania /I The journal is indexed in: PROQUEST I DOAJ / DRJI / JOURNAL INDEX I I2OR / SCIENCE LIBRARY INDEX / Google Scholar / Crossref I Academic Keys / ROAD Open Access / OAJI / Academic Resources / Scientific Indexing Services / SCIPIO

[3] Dobref, V.; 'Utilizarea motoarelor electrice liniare de inducţie la acţionarea instalaţiilor de guvernare ale navelor maritime", Technical University of lassy thesis, lassy 2000.

[4] Grozeanu, S.; „Asupra unor rapoarte energetice la maşina liniară cu indus lichid “, Sielmec '97, Chişinău 1997.

[5] Grozeanu, S.; „Aspecte fundamentale ale propulsării apei de mare cu ajutorul câmpurilor electrice şi magnetice “, Sesiunea naţională de electrotehnică teoretică, Bucureşti 1996. 